\title{
Normal development of fetal hepatic haematopoiesis during the second trimester of gestation is upregulated by fibronectin expression in the stromal cells of the portal triads
}

\author{
D. Tamiolakis, I. Venizelos ${ }^{1}$, S. Nikolaidou and T. Jivanakis ${ }^{1}$ \\ Department of Cytology. General Hospital of Chania. Crete, Greece. ${ }^{\prime}$ Department of Histology-Embryology. Democritus \\ University of Thrace. Medical Faculty. Dragana. Alexandroupolis. Thrace, Greece
}

\section{RESUMEN}

Objetivo: en el segundo trimestre de la gestación, el principal foco de hematopoyesis del feto es el hígado. En los órganos hematopoyéticos, las células del estroma, como fibroblastos, células epiteliales y células de tipo macrófago, desarrollan redes para mantener la hematopoyesis, es decir, la auto-renovación, la proliferación y el crecimiento de las células madre hematopoyéticas, al interactuar con las células progenitoras hematopoyéticas. Se sabe que las glucoproteínas de la MEC producidas por las células del estroma desempeñan un papel crítico en la regulación del crecimiento y la diferenciación celulares. Se han documentado numerosos factores solubles y de membrana que regulan directamente la hematopoyesis, pero se sabe poco de la actividad de las células del estroma hepático y de la proteína (fibronectina) de la matriz extracelular en el feto en relación con la hematopoyesis hepática. La unión de las células eritroides tardías a la fibronectina está bien tipificada y se cree que es crítica para las etapas terminales de la diferenciación eritroide. La intención de este artículo es determinar el papel de la fibronectina en la proliferación y diferenciación hematopoyética del hígado fetal en las distintas etapas del desarrollo.

Material y método: examinamos y comparamos la expresión inmunohistoquímica de fibronectina en los campos portales del estroma hepático durante los trimestres primero, segundo y tercero del embarazo en relación con la aparición de células progenitoras hematopoyéticas CD34, progenitoras del estroma y endoteliales vasculares, respectivamente.

Resultados: nuestros resultados mostraron una diferencia cuantitativa en cuanto a expresión de fibronectina en el estroma del tejido conjuntivo de los campos portales en el segundo trimestre de embarazo respecto al primero ( $p<0,0001$, prueba de la t) y respecto al tercero ( $p<0,0001$, prueba de la t). Se hallaron también cambios similares en cuanto a la expresión de CD34 respecto al primer ( $p<0,0001$, prueba de la $t)$ y el tercer trimestres ( $p<0,0001$, prueba de la $\mathrm{t}$ ), lo que indica la participación directa de la fibronectina en el mantenimiento de la actividad hematopoyética.

\begin{abstract}
Objective: in midtrimester fetuses the principal site of hematopoiesis is the liver. In hematopoietic organs, stromal cells such as fibroblasts, epithelial cells, and macrophage-like cells develop networks to maintain hematopoiesis, i.e. hematopoietic stem cell self-renewal, proliferation, and growth, by interaction with hematopoietic progenitor cells. ECM glycoproteins produced by the stromal cells are known to play a critical role in the regulation of cell growth and differentiation. Numerous soluble and membranebound factors directly regulating haematopoiesis have been documented, but little is known about fetal hepatic stromal cell activity and stromal extracellular matrix protein-fibronectin, on fetal hepatic haematopoiesis. The binding of late stage erythroid cells to fibronectin has been well characterized and is believed to be critical for the terminal stages of erythroid differentiation. The intention of this article is to determine the role of fibronectin in fetal hepatic hematopoietic proliferation and differentiation in different stages of development

Material and method: we examined and compared the immunohistochemical expression of fibronectin in the hepatic stromal portal fields in the $1^{\text {st }}, 2^{\text {nd }}$, and $3^{\text {rd }}$ trimester of gestation respectively, in relation to the appearance of CD34 progenitor hematopoietic, stromal progenitor and vascular endothelial positive cells.

Results: our results demonstrated a quantitative difference in the second trimester of gestation concerning the expression of fibronectin in the connective tissue stroma of the hepatic portal fields over the equivalent expression of the protein in the first $(p<$ 0.0001 , t-test) and third trimester $(p<0.0001$, t-test). Similar changes in the above period were found concerning the expression of CD34 during the second trimester of gestation, over the first ( $p<0.0001$, t-test) and third trimesters ( $p<0.0001$, $t$-test), suggesting a direct involvement of fibronectin in the sustaining of hematopoietic activity.
\end{abstract}


Conclusiones: nuestros datos aportan pruebas de que un componente de la glucoproteína de la MEC, la fibronectina, desempeña un papel importante en la hematopoyesis a través de la interacción entre las células del estroma y las células progenitoras hematopoyéticas.

Palabras clave: Hematopoyesis hepática fetal. Fibronectina. Segundo trimestre de la gestación.
Conclusions: our data provide evidence that an ECM glycoprotein component, fibronectin, plays a relevant role in hematopoiesis through interaction between stromal cells and hematopoietic progenitor cells.

Key words: Fetal liver hematopoiesis. Fibronectin. Second trimester of gestation.

Tamiolakis D, Venizelos I, Nikolaidou S, Jivanakis T. Normal development of fetal hepatic haematopoiesis during the second trimester of gestation is upregulated by fibronectin expression in the stromal cells of the portal triads. Rev Esp Enferm Dig 2007; 99: 576-580.

\section{INTRODUCTION}

Fibronectin (FN) is a multidomain adhesive glycoprotein found in blood and interstitial connective tissue. It interacts with multiple cell surface receptors and plays an important role in the regulation of anchorage-dependent cell growth, cell migration, differentiation, gene expression, tumor development and metastasis, embryogenesis, angiogenesis, and wound healing (1-5).

The reason why the liver is the major haematopoietic site during fetal life is not clear. That the bone marrow is not yet mature this period and that fetal hematopoietic stem cells (HSCs) present specific characteristics do not explain the specific HSC homing to the fetal liver tissue. Stromal cells of the hepatic stromal triads synthesize growth factors, cell adhesion molecules, and extracellular matrix (ECM) molecules which are essential for the establishment of a microenvironment supportive of haematopoietic cell growth and differentiation (6). Fibronectin, a multifunctional ECM glycoprotein found in the fetal hepatic parenchyme (hepatic stromal cells), has been shown to influence the adhesion, migration, growth, and differentiation of many cell types, including hematopoietic cells (7). Interactions of erythroid cells with FN are believed to be essential for erythropoiesis, particularly for the terminal stages of erythroid differentiation (8).

Human haematopoiesis is initiated in the yolk sac during the $3^{\text {rd }}$ week of development (9). The earliest haematopoietic cells (CD34+, CD45+) can be detected during the $5^{\text {th }}$ week of gestation in the aorta-gonadmetanephros region. These cells form compact clusters in close association with the ventral wall of the dorsal aorta $(9,10)$ and then eventually seed in the fetal liver and spleen (10). In contrast, haematopoiesis in the bone marrow commences only about the $12^{\text {th }}$ week of gestation (9). The liver becomes the predominant haematopoietic site from the $6^{\text {th }}$ week of gestation. Bone marrow takes over after birth.

Erythropoiesis comprises the major part of fetal liver hemopoieisis. Most studies performed by light and elec- tron microscopy have shown early development of erythropoiesis in hepatocyte "niches", with continuing maturation within the sinusoids. Cells of erythroid lineage are present in circumscribed clusters in the hepatic parenchyma, which is the place of early erythropoietic development and along the sinusoids where further maturation takes place. Myelomonocytic cells, during the first trimester of gestation, are located mostly in the mesenchymal tissue of the portal triads. In the second trimester the distribution pattern is somewhat different. No main localization is seen in portal spaces, but scattered cells in liver parenchyma and sinusoids are visible. Lymphoid cells are present in small numbers in all stages. These cells are partly scattered throughout the sinuses but, surprisingly, from 16 week onwards, a considerable number of lymphoid cells are also observed in the perivascular connective tissue in the portal triads and around the central veins, which is similar to the localization of myelopoiesis.

The availability of a broad range of monoclonal antibodies (Mabs) recognizing antigens present on cells of different haemopoietic lineages has extended the possibilities for an accurate description of the cells present in these separate lineages and their precursors during different stages of human embryonic and fetal development.

CD34 antigen is a single chain transmembrane glycoprotein with a molecular weight of $110 \mathrm{KD}$. The CD34 protein is selectively expressed on human lymphoid and myeloid haematopoietic progenitor cells. The CD34 protein is also expressed on vascular endothelium.

Our study gives insight into mechanisms of augmentation of hepatic hematopoiesis with fibronectin expression during the second trimester of development.

\section{MATERIAL AND METHODS}

We studied 15 cases of hepatic fetal specimens in different stages of development $\left(1^{\text {st }}, 2^{\text {nd }}\right.$, and $3^{\text {rd }}$ trimester $)$ obtained after voluntary abortion due to leiomyoma (five 
samples), to implantation of the fetus in the region of the internal os resulting in placenta previa (six samples), and to endometriosis-adenomyosis (four samples). All cases were chosen from specific time of development $\left(2^{\text {nd }}\right.$ month: five cases, $5^{\text {th }}$ month: five cases and $8^{\text {th }}$ month: five cases respectively). The study was executed in harmony with the guidelines for the analysis of fetal cells and tissues and approved by the Ethics Committee of the General Hospital of Alexandroupolis. Tissue samples were processed for paraffin section immunophenotyping and stained using the monoclonal antibodies against fibronectin by DAKO and CD34 (NCL-END) by Novocastra. Detection of the antigens in formalin-fixed tissue specimens required antigen-demasking protocols prior to application of antibodies. In most instances this was accomplished using high-pressure cooking (11) in $10 \mathrm{mM}$ citrate buffer at $\mathrm{pH}$ 6.0. Specifically bound antibodies were made visible with the alkaline phospatase-anti-alkaline phosphatase (APAAP) technique (12) using FastRed as chromogen.

The immunostained sections were examined with a X 40 objective and the distribution of fibronectin and NCL-END within the cell was recorded. Every stained cell was scored as positive regardless of staining intensity. To count the number of cells with fibronectin and CD34 stainings, a $10 \times 10$ square calibrated grid was inserted into the eyepiece of an Olympus BX40 binocular microscope.

Five-to-ten fields were examined for each section, and at least 1,000 cells were scored, depending on cellularity. The percentage of positive cells was recorded as the relevant indices.

$$
\begin{aligned}
& \text { Fibronectin }=\frac{\text { no of positive cells }}{\text { no total (positive }+ \text { negative cells) }} \\
& \text { CD34 index }=\frac{\text { no of positive cells }}{\text { no total (positive }+ \text { negative cells) }}
\end{aligned}
$$

The indices ranged from $0-100 \%$, with a mean of $18 \%$. The mean index was evaluated in three ranges: low index (under 18\%), grade I; moderate index (from 18 to $50 \%$ ), grade II; and high index (from 51 to $100 \%$ ), grade III.

We used the parametric method t-test for the statistical analysis of our results because our sample values (cells $/ \mathrm{mm}^{2}$ ) in each case had a normal distribution.

\section{RESULTS}

The sections were examined independently by two observers, and positive cellular staining for fibronectin and CD34 antibodies were manifested as fine red cytoplasmic granularity and/or surface membrane expression.

Hepatic portal triad stromal cells expressed fibronectin in 7 of 15 fetuses-cases during the first trimester $(46.66 \%)\left(32.75 \pm 1.91\right.$ cells $\left./ \mathrm{mm}^{2}\right)$, in all 15 cases during the second trimester $(100 \%)\left(48.61 \pm 4.43\right.$ cells $\left./ \mathrm{mm}^{2}\right)$ and in 8 of 15 cases during the third trimester $(53,33 \%)$ $\left(29.37 \pm 3.29\right.$ cells $\left./ \mathrm{mm}^{2}\right)$.

Progenitor hematopoietic cells, stromal progenitor cells, and vascular endothelial cells expressed CD34 in 10 of 15 fetuses-cases during the first trimester (66.66\%) $\left(55.41 \pm 3.12\right.$ cells $\left./ \mathrm{mm}^{2}\right)$, in all 15 cases during the second trimester $(100 \%)\left(67.93 \pm 4.35\right.$ cells $\left./ \mathrm{mm}^{2}\right)$, and in 13 of 15 cases during the third trimester $(86.66 \%)(101.46 \pm$ 6.76 cells $/ \mathrm{mm}^{2}$ ).

Our results demonstrated a statistically significant difference in the second trimester of gestation concerning the expression of fibronectin in the connective tissue stroma of the hepatic portal fields over the equivalent expression of the protein in the first $(\mathrm{p}<0.0001$, t-test) and the third trimester $(\mathrm{p}<0.0001$, $\mathrm{t}$-test $)$. Similar changes in the above period were found concerning the expression of CD34 over the first $(\mathrm{p}<0.0001, \mathrm{t}$-test) and the third trimester $(\mathrm{p}$ $<0.0001$, t-test) suggesting a direct involvement of fibronectin in the sustaining of hematopoietic activity.

Of 7 fetuse-cases with positive fibronectin expression during the first trimester, 5 were scored as grade I, and 2 as grade III. Of 15 fetuse-cases with positive fibronectin expression during the second trimester, 4 were scored as grade I, 9 as grade II, and 2 as grade III. Immunohistochemical control for fibronectin is shown in figure 1; there is a strong reactivity with the stromal cells of the hepatic portal triads. Of 8 fetuse-cases with positive fibronectin expression during the third trimester, 4 were scored as grade I, 2 as grade II, and 2 as grade III.

Of 10 fetuse-cases with positive CD34 expression during the first trimester, 5 were scored as grade I, 3 as grade II and 2 as grade III. Of 15 fetuse-cases with positive CD34 expression during the second trimester, 3 were scored as grade I, 7 as grade II, and 5 as grade III. Immunohistochemical control for CD34 is shown in figure 2: there is a strong reactivity with the progenitor hematopoietic stem cells, progenitor stromal cells and endothelial cells of the vessels of the hepatic portal triads.

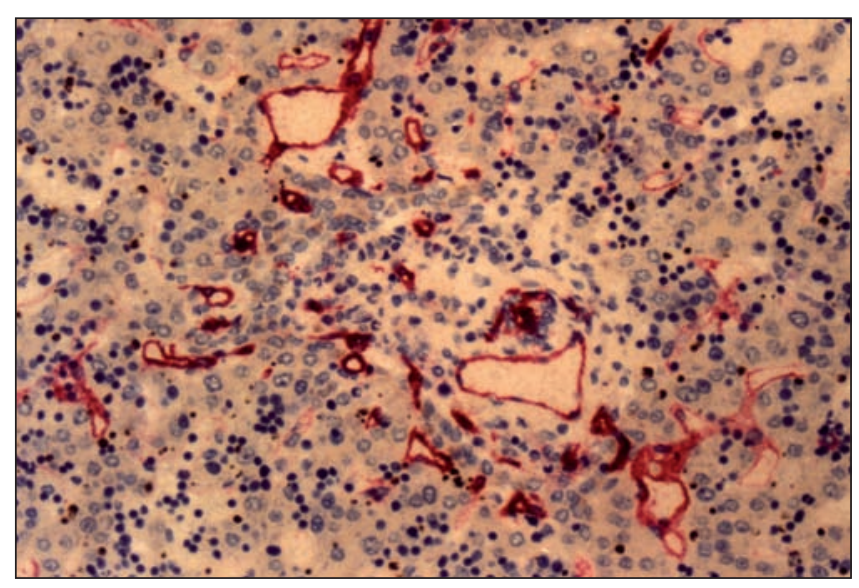

Fig. 1. Fetal hepatic hematopoiesis during the second trimester of gestation. Immunohistochemical control for fibronectin. Immunostain (red labeled cells) X250. 


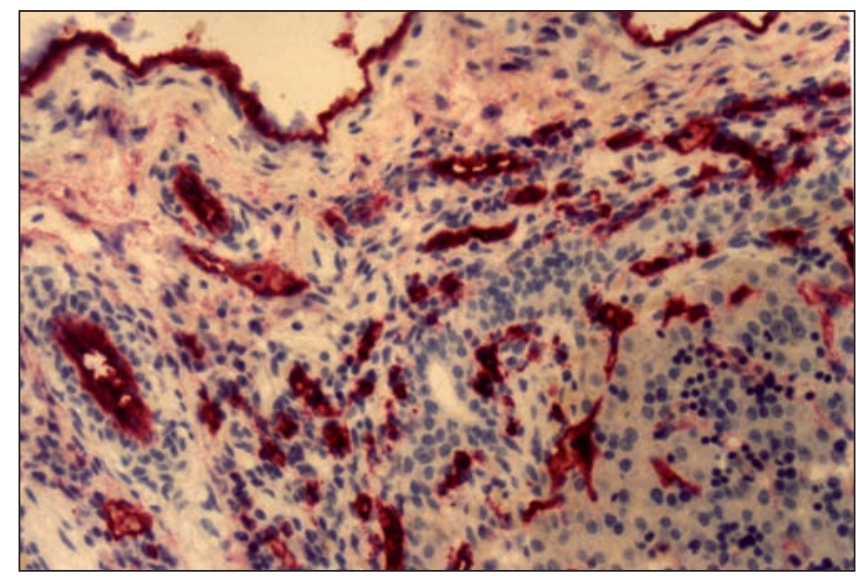

Fig. 2. Fetal hepatic hematopoiesis during the second trimester of gestation. Immunohistochemical control for CD34. Immunostain (red lebeled cells) X250

Of 13 fetuse-cases with positive CD34 expression during the third trimester, 2 were scored as grade I, 8 as grade II, and 3 as grade III.

\section{DISCUSSION}

Over the years, several models have been advanced proposing that haematopoietic lineage determination is driven extrinsically (through growth factors, stroma or other external influences) (13), intrinsically (as described in stochastic models) $(14,15)$, or both $(16,17)$. Within the haematopoietic microenvironment, early progenitors are maintained in specific compartmentalized niches, where they interact with other cell types and components of the extracellular matrix $(18,19)$. The microenvironment has been reported to influence survival, proliferation, and differentiation $(20,21)$. More recently, it has been suggested that the primary function of these extrinsic signals, including growth factors, is to support the survival and development of committed cells, whereas lineage commitment can be attributed to cell intrinsic mechanisms $(14,15,17,22)$. Overall, it appears that the regulation of haematopoiesis is the result of multiple processes involving cell-cell and cell-extracellular matrix interactions, the action of specific growth factors and other cytokines, as well as intrinsic modulators of haematopoietic development.

In most cells, adhesion is an essential process in the control of growth and differentiation and, although hematopoietic progenitor cells can grow in suspension and therefore can bypass this requirement, they have a close association with their stromal extracellular matrix which, under physiological conditions, may regulate interactions with locally available growth factors.

Blood cell formation is controlled by a complex set of events, including interactions between ECM and hematopoietic cells (23). Multiple cell types interact within a confined space in hematopoietic organs to deliver and receive critical signals for proliferation and differentiation. Yokota et al. showed that $\mathrm{FN}$ augments in vitro and in vivo growth of haematopoietic stem cells (24). Treatment of purified human CD34+ cells with FN increased the number of colonies of granulocytemacrophage colony-forming units (CFU-GM), erythroid burst colony-forming units (BFU-E), and mixed erythroid-myeloid colony-forming units (CFU-GEMM). Increased number of CFU-Blast colonies was also observed when EML-C1 cells (a murine multipotent cell line) were pre-treated with FN (24). Therefore, FN seemed to promote colony formation of both committed and uncommitted progenitors, and these effects of FN were seen on a wider stage of differentiation than that reported by Weinstein et al. (25).

Several studies have shown that ligation of FN to integrins stimulate a variety of signaling events, including tyrosine phosphorylation, cytoplasmic alkalization, calcium influx, accumulation of cytoskeletal molecules at sites of cell adhesion, and altered gene expression (26). Attachment of epithelial and endothelial cells to ECM is essential for their survival both in vitro and in vivo because they undergo apoptosis by the inhibition of these interactions (27). In addition, several lines of evidence suggest that signal transduction events through integrin ligand engagement are involved in the suppression of apoptosis in anchored cells. For example, attachment of epithelium to ECM via integrins regulated expression of interleukin 1 beta (IL-1b) converting enzyme, a protein associated with apoptosis (28). Apoptosis of detached endothelial cells was suppressed by the addition of sodium vanadate, a protein tyrosine phosphatase inhibitor (29). Among the signals via integrins, pp125 focal adhesion kinase (pp125FAK) is particularly of interest because constitutive activation of pp125FAK was sufficient to rescue an epithelial cell line, Madin-Darby Canine Kidney (MDCK) cells, from apoptosis. Moreover, injection of an anti-pp125FAK antibody into rounded fibroblasts resulted in the rapid onset of apoptosis. It is also known that pp125FAK directly associates with $\beta$ subunit of integrins, and its tyrosine phosphorylation and kinase activity are upregulated by the binding of FN to integrins (30). It seems it would be of interest to evaluate roles of pp125FAK in apoptosis of EML-C1 cells, a multipotent hematopoietic cell line. Further analysis will be necessary to reveal the signal transduction pathway and structural basis of FN for promoting cell survival and growth.

All types of hemopoietic cells derive from a small pool of immature uncommitted progenitor cells. During the past few decades the phenotype of the hemopoietic progenitors has been analyzed in detail. The first "precursor cell antigen" to be described was HPCA-1 (CD34). This antigen is expressed on (almost) all types of hemopoietic progenitors. However, CD34 is also expressed on stromal cell progenitors and even on vascular endothelium. Fibronectin, one of the components of ECM molecules, 
plays an important role in the regulation of hematopoietic differentiation.

The mechanism(s) of action of fibronectin on hematopoietic stem cell and microenvironment remain to be determined; however, fibronectin may possibly act by increasing binding of hematopoietic cells to stromal cells and by increasing the utilization of hematopoietic growth factors by the stem cells cooperating with other ECM molecules.

In our series: a) the comparative study of the quantitative percentage of fibronectin expression at $1^{\text {st }}, 2^{\text {nd }}$ and $3^{\text {rd }}$ trimester of gestation showed a statistically significant difference in the number of stromal cells in the portal triads of the hepatic parenchyme during the second trimester over the first $(\mathrm{p}<0.0001$, $\mathrm{t}$-test) and third trimesters $(\mathrm{p}<$ 0.0001 , t-test); and b) the comparative study of the quantitative percentage of CD34 for the identification of progenitor hematopoietic cells, stromal progenitor cells, and vascular endothelial cells at $1^{\text {st }}, 2^{\text {nd }}$ and $3^{\text {rd }}$ trimester of gestation showed a statistically significant difference in the number of the relevant cells of the hepatic parenchyme during the second trimester over the first ( $p<0.0001$, $\mathrm{t}$-test) and third trimesters $(\mathrm{p}<0.0001, \mathrm{t}$-test).

Our results imply that the expression of fibronectin in higher amounts during the second trimester of gestation provides evidence that this specific extracellular matrix glycoprotein induces the hemopoietic progenitor cell proliferation and differentiation in the fetal liver.

\section{REFERENCES}

1. Mosher DF. Physiology of fibronectin. Annu Rev Med 1984; 35 : 561 75 .

2. Ruoslahti E. Fibronectin and its receptors. Annu Rev Biochem 1988; 57: 375-413.

3. Yamada KM, Clark RAF. Provisional matrix: The molecular and cellular biology of wound repair. In: Clark RAF, editor. New York: Plenum Press. p. 51-93.

4. Schwarzbauer JE. Fibronectin: From gene to protein. Curr Opin Cell Biol 1991; 3: 786-79.

5. Humphries MJ. Fibronectin and cancer: rationales for the use of antiadhesives in cancer treatment. Semin Cancer Biol 1993; 4 (5): 293-9.

6. Martin MA, Bhatia M. Analysis of the human liver hematopoietic microenvironment. Stem Cells Dev 2005; 14 (5): 493-504.

7. Chagraoui J, Lepage-Noll A, Anjo A, Uzan G, Charbord P. Fetal liver stroma consists of cells in epithelial-to-mesenchymal transition. Blood 2003; 101 (8): 2973-82.

8. Vuillet-Gaugler MH, Breton-Gorius J, Vainchenker W, Guichard J, Leroy $\mathrm{C}$, Tchernia $\mathrm{G}$, et al. Loss of attachment to fibronectin with ter- minal human erythroid differentiation. Blood 1990; 75: 865-73.

9. Charbord P, Tavian M, Coulombel L, Luton D, Clemente SH, Humeau L, et al. Early ontogeny of the human hematopoietic system. C R Seances Soc Biol Fil 1995; 189: 601-9.

10. Tavian M, Coulombel L, Luton D, San Clemente H, Humeau L, Dieterlen-Lievre F, et al. Aorta-associated CD34+ hematopoietic cells in the early human embryo. Blood 1996; 87: 67-72.

11. Norton AJ, Jordan S, Yeomans P. Brief, high-temperature heat denaturation (pressure cooking): A simple and effective method of antigen retrieval for routinely processed tissues. J Pathol 1994; 173: 371-9.

12. Cordell JL, Falini B, Erber WN, Ghosh AK, Abdulaziz Z, MacDonald $\mathrm{S}$, et al. Immunoenzymatic labeling of monoclonal antibodies using immune complexes of alkaline phosphatase and monoclonal antialkaline phosphatase (APAAP complexes). J Histochem Cytochem 1984; 32: 219-29.

13. Watt F, Hogan B. Out of Eden: Stem cells and their niches. Science, 2000; 287: 1427-30.

14. Ogawa M. The stochastic model revised. Int J Hematol 1999; 69: 2-5.

15. Ogawa M. Differentiation and proliferation of hematopoietic stem cells. Blood 1993; 81: 2844-53.

16. Just U, Friel J, Heberlein C, et al. Upregulation of lineage specific receptors and ligands in multipotential progenitor cells is part of an endogenous program of differentiation. Growth Factors 1993; 9: 291-300.

17. Tenen DG, Hromas R, Licht JD, et al. Transcription factors, normal myeloid development, and leukemia. Blood 1997; 90: 489-519.

18. Taichman RS, Emerson SG. The role of osteoblasts in the hematolopoietic microenvironment. Stem Cells 1998; 16: 7-15.

19. Potonic AJ, Brakebush C, Fassler R. Fetal and adult hematopoietic stem cells require beta 1 integrin function for colonizing fetal liver, spleen and bone marrow. Immunity 2000; 12: 653-63.

20. Rafii S, Mohle R, Shapiro F, et al. Regulation of hematopoiesis by microvascular endothelium. Leuk Lymphoma 1997; 27: 357-86.

21. Torok-Storb B, Iwata M, Graf L, et al. Dissecting the marrow microenvironment. Ann N Y Acad Sci 1999; 872: 164-70.

22. Cross MA, Enver T. The lineage commitment of hematopoietic progenitor. Curr Opin Genet Dev 1997; 7: 609-13.

23. Long MW, Briddell R, Walter AW, Bruno E, Hoffman R. Human hematopoietic stem cell adhere to cytokines and matrix molecules. J Clin Invest 1992; 251.

24. Yokota T, Oritani K, Mitsui H, Aoyama K, Ishikawa J, Sugahara H, et al. Growth-supporting activities of fibronectin on hematopoietic stem/progenitor cells in vitro and in vivo: Structural requirement for fibronectin activities of CS1 and cell-binding domains. Blood 1998; 91 (9): 3263-72.

25. Weinstein R, Riordan MA, Wenc K, Kreczko S, Zhou M, Dainiak N. Dual role of fibronectin in hematopoietic differentiation. Blood 1989; 73: 111-6.

26. Juliano RL, Haskill S. Signal transduction from the extracellular matrix. J Cell Biol 1993; 120: 577.

27. Frisch SM, Francis H. Disruption of epithelial cell-matrix interactions induces apoptosis. J Cell Biol 1994; 124: 619-26.

28. Boudreau N, Sympson CJ, Werb Z, Bissell MJ. Suppression of ICE and apoptosis in mammary epithelial cells by extracellular matrix. Science 1995; 267: 891-9.

29. Meredith HE, Fazeli B, Schwartz MA. The extracellular matrix as a cell survival factor. Mol Biol Cell 1993; 4: 953-61.

30. Hungerford JE, Compton MT, Matter ML, Hoffstrom BG, Otey CA Inhibition of pp $125 \mathrm{FAK}$ in cultured fibroblasts results in apoptosis. J Cell Biol 1996; 135: 1383-90. 